\title{
Evaluating the Strategy to optimize the Retakaful Treaty Property Insurance: In the Perspective of the Sharia General Insurance Company in Indonesia
}

\author{
Iwan Hermawan, Noer Azam Achsani, Laily Dwi Asyanti
}

Institute Pertanian Bogor School of Business, Indonesia.

Corresponding Author: Iwan Hermawan

DOI: https://doi.org/10.52403/ijrr.20220145

\begin{abstract}
Purpose: This study on the potential strategy to optimize the retakaful treatyproperty insuranceof the Indonesian sharia general insurance company. Those potential strategies are the priority strategy and alternative strategy.The company can design a piority strategy to optimize the retakaful treaty contract so as to minimize problems arising from the implementation of the underwriting and claim handling.

Design/methodology/approach: Thedesign of this research is descriptive - qualitative.A survey on the reinsured's retakaful existing strategy, retakaful treaty program, internal and external factors, the company's position and implementation ofits business process werealso conducted for this study. Several alternative strategies were obtained using Strength, Weakness, Opportunity (SWOT) analysis and the priority strategyis determined by the Quantitative Strategic Planning Matrix (QSPM) analysis.

Finding: The findings from the survey of the evaluation of reinsured's retakaful existing strategies are: An alternative strategy obtained by using a SWOT matrix analysis, where the company's position in quadrant $I$ with a progressive strategy. The strategy is in accordance with the results of the company's position analysis using the IE matrixwhere the company is in quadrant II in the position of Growth and build. The suitable strategy is to use intensive, forward, backward and horizontal integration. By using the QSPM, the priority strategy is that the company can design a quality retakaful treaty contract.
\end{abstract}

Research Limitation/Implications: This study is limited to Indonesian's retakaful experience. The strategy being evaluated is the reinsured's retakaful existing strategy. The findings are the the priority strategy and alternative strategy. The company can design a priority strategy regarding the retakaful treaty contract to optimize the treaty program.

Practical Implications: By evaluating the reinsured's existing strategy in the retakaful treaty, the sharia general insurance company can design a quality retakaful treaty contract to optimize the treaty program. The study may also aid the researchers and regulators to discuss on the area for further development of sharia insurance industry.

Social Implications: Based on the findings and implications, it can give managerial implication to the sharia general insurance company and convince the government to speed up the other retakaful business units to spin off becoming a professional reinsurance company. So the numbers of the sharia reinsurance companies in Indonesia will increase and moreover strengthen the sharia insurance industry.

Originality/value: The insights on the respondent's experience when explaining the internal and external factors, company's position related to the strategy on optimizing retakaful treaty can assist the sharia generalinsurance companies to manage the risks and have a priority strategy to set up their underlying retention and get the claim recovery from the reinsurer.

Keywords: Priority Strategy, Retakaful Treaty, Property insurance, Sharia general insurance company 


\section{INTRODUCTION}

The retakaful or sharia reinsurance is needed by a general insurance company to reduce the impact of the particular risks and catastrophic risks. Indonesia is among the 10 most disasters countries and from 2005 to 2014 ranked fifth based on data from the 2018 Reinsurance Market Survey. In terms of frequency and severity, the catastrophic risk has affected Indonesia around 141 disasters with a total loss of USD 11 billion.

Retakaful risk is included in the category of risk faced by sharia general insurance company during operations such as: credit risks, liquidity risks, market risks, insurance risks and operational risks. The lack of availability of support for automatic reinsurance capacity or treaty in the country stimulates thesharia general insurance companies to seek additional capacity for its shortage by purchasing retakaful program from overseas reinsurers. This will affectan invisible earnings coming out of the country through reinsurance premium payments abroad.

Another issue for sharia general insurance companies how to get retakaful programs from sharia reinsurance company despite it is only permitted to place the risk to retakaful company. On the other hand there is only one full pledged sharia reinsurance company In Indonesia (PT. Indonesia Reasuransi Syariah).Based on the data of the the General Insurance Association of Indonesia (AAUI) in 2019 the sharia insurance industry in Indonesia consist of: seven sharia life insurance companies, five sharia general insurance companies and one sharia reinsurance company. The others are still in the form of retakaful business units.

Some sharia general insurance companies are more risk averse than others because they do not want a concentration of responsibility for a type of business. In order to protect their new business, they bought the retakaful treaty program for the purpose of avoiding undesirable effects on this new business. For sharia general insurance companies who already exist want to develop new products based on existing portfolios they are more likely to choose risk insurance from reinsurers while the others buy fewer retakaful programs. Theyalso can take benefit from the retakaful treaty program such as: sharing experiences and staff training. By nurturing the good relationship with the reinsurance company, the sharia insurance companies will get better business results.

The sharia general insurance companies often have to take more risks that they can choose and may seek comfort by buying a retakaful program. Theyneed to set priorities for a number of risks that are ready to be borne by their business. They are faced by thepractical limitations on the level of needs of the retakaful treaty program with low operational of profit or even none.Sometimethey are trapped in the need of attracting prospective clients and finding a place in the insurance market to develop their new business.

Referring to the above circumstances, we evaluate the strategy on optimizing retakaful treaty property insurance from the perspective of the sharia general insurance companies. This study particularly aims to:

1. Identify the reinsured's retakaful existing strategy,

2. Measure internal and external factors using Internal Factor Evaluation Matrix (IFE Matrix) and External Factor Evaluation Matrix (EFE Matrix),

3. Determine the company's positionusing Internal and External Matrix (IE Matrix)

4. Design several alternative strategiesusing Strength, Weakness, Opportunity (SWOT) analysis.

5. Decide the priority strategy using Quantitative Strategic Planning Matrix (QSPM) analysis

6. Elaborate the reinsured's retakaful treaty program

7. Evaluate the implementation ofretakaful business process 


\section{MATERIALS AND METHODS}

The design of the research is descriptive-qualitative which aims to evaluate the strategy of the sharia general insurance company on optimizing retakaful treaty property insurance in one particular time and through examples that can represent the research. This descriptive research design applies survey data by taking information from some examples of a population, namely PT. Asuransi Jasindo Syariah (AJS) and other four sharia general insurance companies in Indonesia. They are: PT. Asuransi Takaful Umum, PT. Asuransi Sonwellis Takaful, PT. Asuransi Askrida Syariah, and PT. Jaya Proteksi Syariah as the samples.
We conducted the research from October 2019 to January 2020at PT. Asuransi JasindoSyariah (AJS) in Indonesia. We also collaborated with the AJS's tim for distributing questionnaire and interview. The sampling technique uses primary data. Primary data is obtained from survey and interview with internal and external sources of the companies through direct respondents and questionnaires. The secondary data is obtained from the literature review ofthe international journals, thesis, books, annual reports, financial reports, reinsurance guidelines, property insurance policies, websites, MUI fat was, $\mathrm{Had}$ its and $\mathrm{Al}$ Qur'an. Both primary and secondary data are combined for the study purpose. The primary and the secondary data are as follow:

Table 1: The primary and the secondary data

\begin{tabular}{|c|l|l|}
\hline No. & \multicolumn{1}{|c|}{ Description } & \multicolumn{1}{c|}{ Source } \\
\hline 1. & Vision and mission of the company & Annual Report (Secondary data) \\
\hline 2. & Strategy and policy of the company & Interview (Primary data) \\
\hline 3. & Retakaful treaty program & Reinsurance guideline (Secondary data) \\
\hline 4. & Risk covered in retakaful treaty Property Insurance & Reinsurance guideline, PSAKI and P/IAR policy (Secondary data) \\
\hline 5. & Retakaful treaty business process & Interview (Primary data) \\
\hline 6. & Sharia Insurance data statistic & AASI \& AAUI market update (Secondary data) \\
\hline
\end{tabular}

The sampling technique in this study is a purposive sampling technique where researchers take samples based on specific considerations and objectives (judgment sampling). The judgement sampling of the field survey focused on the academics, practitioners, regulators and selected speakers which have certain criteria.The criteria were having: a minimum education from university, sharia knowledge, expertise and competency of reinsurance techniques, experience for more than three years in the reinsurance section. Since the sampling method is the purposive sampling, so we select therespondents with the specific objectives. The specific purpose intended here is for the researcher to determine the sample taken based on certain considerations and objectives (judgment sampling). They are: an academics, a practitioner (having experience more than three years in the reinsurance unit) and the regulator.
One of the sampling respondent is PT. Asuransi JasindoSyariah (AJS). AJSis established in 2016 as a general insurance company with sharia principles.It was first formed as a result of the business separation (spin-off) of the PT. AsuransiJasa Indonesia (Persero). AJS generally has three product categories, namely: General Insurance, Bundling Product and Micro Insurance. AJS provide wider insurance choices for customers, through products that are in accordance with the needs of the community using the principles of Islamic law. AJS's vision: "Becoming a reliable and trusted sharia insurance company. AJS's mission: Carrying out sharia insurance business by always optimizing participant funds through the application of excellent service. PT. Jasindo Syariah Insurance only has six business lines, namely: Marine Cargo Insurance, Property Insurance, Engineering Insurance, Marine Hull Insurance, Motor Vehicle Insurance and Miscellaneous Insurance. 
Iwan Hermawan et.al. Evaluating the strategy to optimize the retakaful treaty property insurance: in the perspective of the Sharia General Insurance Company in Indonesia

\section{Retakaful Treaty Programs}

The definition of reinsurance business according to the Law of the Republic of Indonesia No. 40 of 2014 concerning Insurance, namely: "The business of reinsurance services against the risks faced by insurance companies and other reinsurance companies". While the definition of Retakaful is: "The risk management business is based on sharia principles for the risks faced by sharia insurance companies, sharia guarantee companies or other sharia reinsurance companies".

According to Paul (2009) in a book titled Reinsurance, The Chartered Insurance Institute (CII), United Kingdom, the reinsurance goals includes:

1. Spreads Risk

2. Increases Capacity

3. Security Provides

4. Increases Stability in Results

5. Increases Confidence

6. Portfolio and asset management

7. Taxation Advantages

8. Cash flow advantages

9. Corporate Strategy.

Based on the CII reinsurance text book, Paul (2009) also said: "There are two types of reinsurance: Treaty and
Facultative. The definition of reinsurance treaty is: "accepts a large number of similar risks. Treat or accept a large amount of risk from a similar risk". Whereas the definition of facultative reinsurance is: "individual reinsurance of large/hazardous single risk or Facultative is an individual reinsurance that accepts every single risk in a large amount".

The reinsurance method is also divided into two ways, namely:" Proportional and Non-Proportional. Proportional reinsurance method, insurance companies allocate each proportion of risk to reinsurers. Then the reinsurer accepts each portion of the risk and pays the same portion for his claim to the insurance company. While the Non-Proportional reinsurance method, reinsurers will only pay claims when it exceeds the specific retention of the insurance company. Own retention of insurance companies is often called monetary amount/underlying retention (UR)".

To give an understanding of the retakaful business process, below is a diagram of the Insurance, Reinsurance/ Retakaful and Retrocession business process.

Table 4: Business Process of Insurance, Reinsurance/Retakaful and Retrocesion

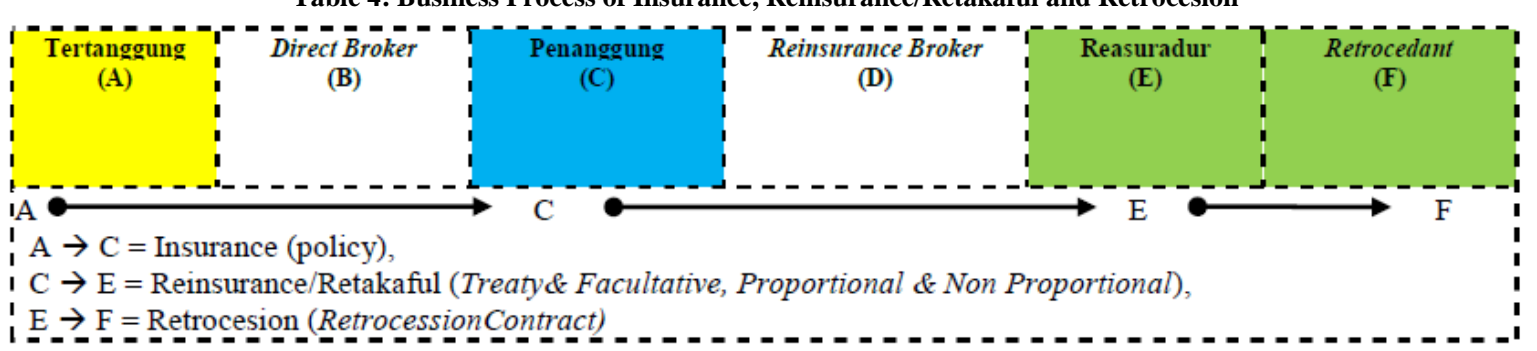

Insurance business process is started from the request for insurance protection services from the participants/Insured, and then the Insurers will offer insurance, negotiate and accept the risk. The policy is issued and the contribution/premium must be paid. If in the current period of insurance there is a claim, the Insurer will process the claim.
Reinsurance business process is started when the insurer request the reinsurance program. If the insurers have a retakaful treaty program they can use it to increase their capacity by making the payment of the contribution/premium of retakaful and wakalah fees (fees for the representatives). This process can runs parallel in the insurance business process. 
There is a slight difference between conventional reinsurance practices with retakaful. In sharia insurance the reinsurance mechanism is risk sharing so in risk management, the sharia insurance company as the ceding company must share the wakalah fee which they have been received to the sharia reinsurance company. Whereas in conventional insurance is risk transfer, the conventional reinsurance company will give a reinsurance commission to the insurance company which has given them the business.

Retrocession business process is a reinsurance transaction where the reinsurers are assigned to other fellow reinsurers all or part of the reinsurance program business. Retrocession contracts are typically as reinsurance contracts that apply standards in the global reinsurance market. The buyer of retrocession is called as the Retrocedant.

Based on the reinsurance guideline, the type retakaful treaty programs adapted by the sharia general insurance companies in Indonesia as follows:

\section{Treaty Proportional Share Quota.}

In the Quota Share proportional treaty method, the insurance / ceding company must assign a fixed percentage of all risks. Instead reinsurers are required to accept all sessions a fixed percentage of all these risks. Example: if a reinsurer receives $20 \%$ of the risk session, then the reinsurer will also receive a $20 \%$ premium and pay $20 \%$ of the claim.

\section{Treaty Proportional Surplus}

In this Surplus reinsurance method, it will work until a sum insured exceeds the retention in a category; no risks are ceded to the reinsurance. The capacity in a surplus is usually many times that of insurance company retention in the form of a line. The term "line" is: an amount of money from an insurance company's gross retention taken as original risk. Example: there are 10 lines Surplus subject to maximum cession; USD $5,000,000$ any one risk. 1 line $=$ USD 500,000 . This means that 10 lines $=$ USD $500,000 \times 10=$ USD 5,000,000. If added 1 line of original risk of USD 500,000 so that the maximum capacity of the proportional reinsurance surplus will be: USD 5,500,000.

\section{Treaty Proportional Facultative Obligatory}

Is a form of treaty to place some parts of an individual's risk. This type of treaty combines several principles of facultative and proportional treaty reinsurance methods. As we know in the treaty, the contract is made at the beginning, but once the treaty is valid, the insurance company has the choice whether to assign the risk to the reinsurer or not. The obligatory element is in the reinsurer who will receive the part. In short insurance companies may assess the risks of certain lines of insurance that reinsurers must accept.

4. Treaty Non Proportional Excess of Loss

Characteristics of the Treaty NonProportional Excess of Loss method of reinsurance in Property Insurance, namely: the distribution of liabilities on a basis of losses rather than Sum Insured. Reinsurance will receive part of the original premium but not part of the premium related to the insurance price. Session size is not determined case by case (cession bordereaux). Example: Excess of Loss with underlying retention of an insurance company every time there is a loss per sum insured of Rp. $1,500,000,000$. If there is a claim of Rp. 5,000,000,000, the reinsurer will pay a claim in excess of the excess of the insurance company's underlying retention so that the amount of claim recovery paid by the reinsurer is: $\mathrm{Rp}$. 5,000,000,000-Rp. $\quad 1,500,000,000=$ Rp. $3,500,000,000$.

\section{Treaty Non Proportional Stop Loss}

The Stop Loss insures the aggregate losses arising from certain insurance lines rather than individual risks. Stop Loss contracts are represented as a percentage of the Gross Net Rate Premium Income (GNRPI). 
These types of treaty non proportional Excess of Loss and Stop Loss are still used bythe one of the sharia general companies in Indonesia (Darurah). Despite it has not been detailed in regulating the jurisdiction of the Shariah Supervisory Board as a supervisor of shariah principles in the sharia general insurance companies.

\section{Property Insurance}

Wehave chosen theline of business Property Insurance because based on the data from AAUI in 2019 the insurance product which contributed the highest market share was dominated by Property Insurance. Retakaful treaty property insurance can be in the form of various type of risks inherent the operations of the target of respondent. For instance: property/ Industrial risks, business interruption, theft and earthquake. The definition of Property Insurance according to SE OJK No. 6/SEOJK.05/2017 namely: "insurance that insures property against the risk of Fire, Lightning, Explosion, Aircraft impact and Smoke (FLEXAS) covered on Indonesian Fire Insurance Standard Policy (PSAKI) issued by the Indonesian General Insurance Association (AAUI), including but not limited to Munich Re wording Industrial All Risks (IAR) policies, Munich Re wording Property All Risks (PAR), Commercial All Risks, Manuscript wording, Association of British Insurers (ABI) wording, Mark IV/V, Comprehensive Machinery Insurance, Electronic Equipment Insurance and other property policies that cover FLEXAS risks".

Based on this understanding, it can be concluded that Property Insurance is a type of coverage that gives protection against the risk of FLEXAS risks. For additional information there are twotypes of property insurance wordings policy which are usually used by the sharia general insurance companies in Indonesia. They are Indonesian Fire Insurance Standard Policy (PSAKI)and Property/Industrial All Risks (P/IAR). In accordance with the provisions of the class of business covered in the overview section of the Property Insurance retakaful treaty contract, the risks covered are the insured perils in the Indonesian Fire Insurance Standard Policy (PSAKI), namely: Fire, Lightning, Explosion, Aircraft impact and Smoke. They are commonly abbreviated as FLEXAS. On the otherhand, the Property/Industrial All Risks (P/IAR) covers all risks.

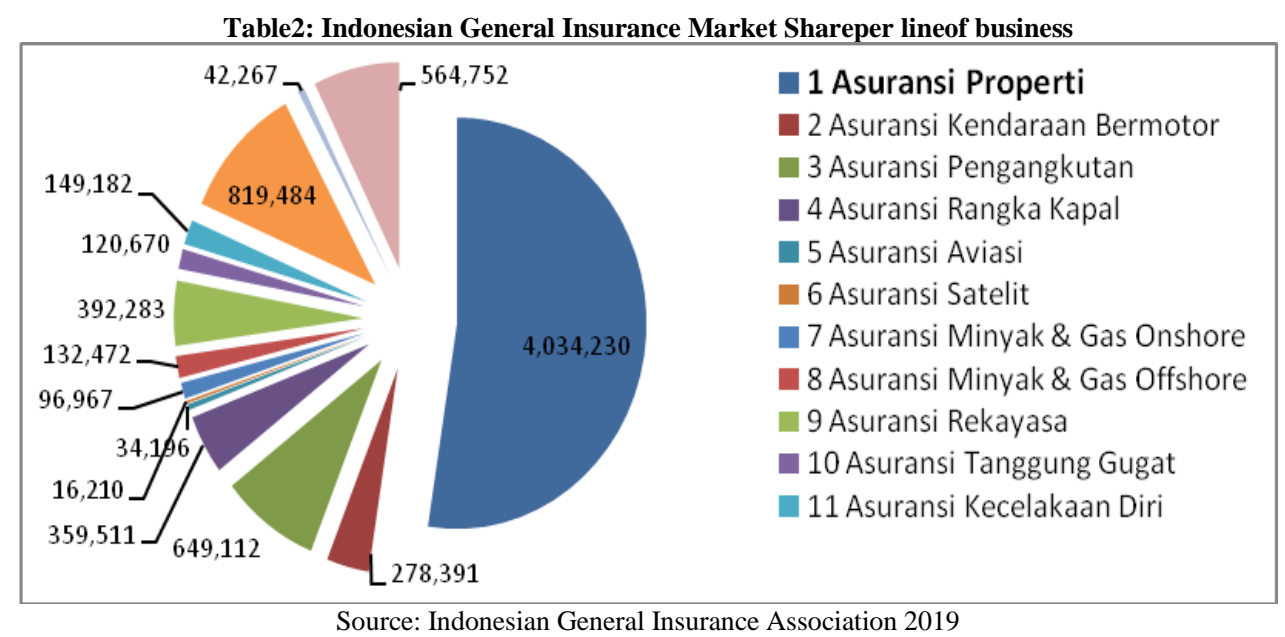

\section{Statistical Methods}

The survey questionnaire was design to understand the existing strategy, evaluating internal and external factors, analyzing company's position, designing alternative strategy, determining priority strategy and evaluating the implementation of retakaful treaty property insurance. When evaluating internal and external factors we used Internal Factor Evaluation Matrix (IFE Matrix) and External Evaluation Matrix (EFE Matrix). The company's position is 
analyzed by Internal and Internal Matrix (IE Matrix). Alternative strategy is obtained by using a Strength, Weakness, Opportunity; Threat Matrix (SWOT matrix analysis). The priority strategy is analyzed by using the Quantitative Strategic Planning Matrix (QSPM analysis). Processing techniques and data analysis procedures in this study adopt the descriptive analysis. The collecting and processing of the data or information is either from the internal and external speakers. The data or information is as follows:

Table 3:List of the selected respondents and speakers

\begin{tabular}{|c|l|l|l|}
\hline No. & \multicolumn{1}{|c|}{ Name of Respondent } & \multicolumn{1}{|c|}{ Occupation \&Period } & \multicolumn{1}{c|}{ The collected Data } \\
\hline 1. & $\begin{array}{l}\text { Saparudin, SE, Ak, CA, MBA, CMA, } \\
\text { AAAIK }\end{array}$ & $\begin{array}{l}\text { Direktur Utama PT. Asuransi Jasindo } \\
\text { Syariah, 2 years }\end{array}$ & Strategy and policy of AJS (Primary Data) \\
\hline 2. & $\begin{array}{l}\text { Dr Reza Ronaldo MM, CGI, APAI, } \\
\text { CIIB, ANZIIF (Senior Assoc.) CRGP } \\
\text { Jirektur Operasional PT. Asuransi } \\
\text { Jasindo Syariah, 1 year }\end{array}$ & $\begin{array}{l}\text { Internal } \\
\text { Strategy (Primary Data) }\end{array}$ \\
\hline 3. & $\begin{array}{l}\text { Setiawan Bahrun S.SOS, AAAIK, AMII, } \\
\text { AIIS, CRMP }\end{array}$ & $\begin{array}{l}\text { Kadiv Teknik PT. Asuransi Jasindo } \\
\text { Syariah, 4 year }\end{array}$ & $\begin{array}{l}\text { Retakaful treatybusiness process (Primary } \\
\text { Data) }\end{array}$ \\
\hline 4. & $\begin{array}{l}\text { Indra Perwira, ST, AAIK, FIIS, AMII, } \\
\text { ACII, ICPU }\end{array}$ & $\begin{array}{l}\text { Departemen Head Underwriting PT. } \\
\text { Asuransi Jasindo Syariah, 5 year }\end{array}$ & $\begin{array}{l}\text { Loss record of risk covered in retakaful } \\
\text { treaty Property Insurance (Primary Data) }\end{array}$ \\
\hline 5. & $\begin{array}{l}\text { Imam Rosadi, SE, MAK, SAS, AAAIK, } \\
\text { AIIS }\end{array}$ & $\begin{array}{l}\text { Head of Accounting Department PT. } \\
\text { Asuransi Jasindo Syariah, 4 year }\end{array}$ & Financial report (Secondary data) \\
\hline 6. & Erwin Noekman, ACII, FIIS & Chairman of AASI, 5 year & AASI market update (Secondary data) \\
\hline 7. & Dr. Widyo Gunadi & $\begin{array}{l}\text { Regulation of OJK Institute, 2 year } \\
\text { (Secondary data) }\end{array}$ \\
\hline
\end{tabular}

\section{RESULTS}

Findings from the survey questionnaire were identified and analyzed according to the key areas of survey findings as follows:

\section{Identifying the company's existing strategy}

According to the survey responses of the interviews with the company's internal persons and the PT. AJS reinsurance guidelines 2019, the company's existing strategy on optimizing the retakaful treaty programsare as follows:

1. The company still emphasizes the banking sector.

From the achievement of existing production, it was mostly obtained from bank financing, namely from the Miscellaneous Insurance and Motor Vehicle Insurance business.

2. Keep continuing to grab the banking and retail sectors.

By developingthe insurance agency system and applying theinsurance digital applications to help marketing products to the prominent customer.

3. The company will also work on the corporate sector such as the Property Insurance, Engineering Insurance and Marine Hull Insurance businesses. Increasing co-insurance cooperation with the other insurance companies and nurturing cooperation with insurance broker companies.

4. In carrying out its business operations, the company is supported by retakaful programs both treaty and facultative reinsurances. In order to optimize the local reinsurance capacity, the company used domestic sharia general reinsurance services.

\section{Evaluating Internal Factors}

The strategic management process according to David (2009) consists of three stages: "strategy formulation, strategy implementation and strategy evaluation. Strategy formulation is a combination of orientation towards future perspectives with external and internal circumstances of the company today". The company's Internal Factor Evaluation (IFE) results have been identified analyzed and evaluated using the IFE matrix by weighting and ranking. Giving weights is done by the paired comparison method. This method is best used to measure the relative importance of a number of alternatives that have interesting possibilities to be chosen. Giving weights to this method with a scale of $1-3$ is to compare an internal factor with one another. A weight value of 1 is given if an internal factor is less important than other internal 
factors. A weight value of 2 is given if an internal factor is as important as another internal factor. And the weight value of 3 is given if an internal factor is more important than other internal factors. Furthermore, the ranking value is divided into 2, namely strength and weakness. For strength ranking is defined as the main strength if the respondent gives a value of 4 and a minor strength if the respondent gives a value of 3 on the internal factor being analyzed. As for the rating of Weakness is defined as the main weakness if the respondent gives a value of 2 and is a minor weakness if the respondent gives a value of 1

Determination of the weight and ranking is done through a questionnaire to all sources both internal and external. After weighting and ranking is done, then multiplying the weight and ranking will get the value of the weighted weight score which shows the company's ability in general to use internal factors in the form of Strengths and Weaknesses in implementing the retakaful treaty Property Insurance program. The results of evaluations of internal factors are the average values obtained from internal and external sources that can be seen in the table below:

Table 5: the IFE matrix

\begin{tabular}{|c|l|c|c|c|}
\hline No. & \multicolumn{1}{|c|}{ Internal Factors } & Weight & Rating & Score \\
\hline & \multicolumn{1}{|c|}{ Strengths } & & & \\
\hline 1 & Reinsurance experience (1) & 0.112 & 4 & 0.447 \\
\hline 2 & Human Resource (2) & 0.101 & 4 & 0.404 \\
\hline 3 & Financial Capacity (3) & 0.112 & 3 & 0.335 \\
\hline 4 & IT Support (4) & 0.101 & 3 & 0.303 \\
\hline 5 & Image (5) & 0.096 & 3 & 0.287 \\
\hline & Weaknesses & & & \\
\hline 1 & Vision, Mission \&Policy(6) & 0.106 & 1 & 0.106 \\
\hline 2 & SOP and SLA (7) & 0.096 & 1 & 0.096 \\
\hline 3 & Business Portofolio (8) & 0.096 & 1 & 0.096 \\
\hline 4 & Business Proses (9) & 0.090 & 1 & 0.090 \\
\hline 5 & Teamwork(10) & 0.090 & 1 & 0.090 \\
\hline & Total IFE & $\mathbf{1}$ & & $\mathbf{2 . 2 5 5}$ \\
\hline
\end{tabular}

The IFE matrix can also be used to find out the main strengths and weaknesses of the company in optimizing the retakaful treaty Property Insurance program. The total weighted score on the IFE matrix is 2,255. This shows the company's position which is almost strong enough, both in optimizing strengths and minimizing weaknesses. The company's reinsurance experience is a superior strength factor to learn from the previous experience of retakaful treaty. While the company's goals and policies related to the retakaful treaty programs are the main weaknesses that must be corrected. This is quite reasonable considering that of the many cases of fire claims were becoming the company's retention and there are only two cases of fire claims involving retakaful treaty Property Insurance program.

\section{Evaluating External Factors}

The Company's External Factors Evaluation results that have been identified, analyzed and evaluated using the EFE matrix by giving weights and ratings. Giving weights is done by the paired comparison method. Giving weights to this method with a scale of 1-3, namely comparing one external factor with another. A weight value of 1 is given if an external factor is less important to other external factors. A weight value of 2 is given if an external factor is as important as another external factor. And the weight value of 3 is given if an external factor is more important than other external factors. Furthermore, rating ratings for external factors are based on the level of response from the company to these external factors. A value of 1 is given if the company's response is below average, a value of 2 is given if the company's response is average, a value of 3 is given a company response above average and a value of 4 is given if the company's response is extraordinary. The higher the company's response rate, the more important the threat or threat is responded to and followed up by the company.

Determination of the weight and ranking is done through a questionnaire to all sources both internal and external. After assigning weights and ratings, multiplying the weights and ratings will obtain a weighted score which indicates the company's ability in general to respond to external factors in the form of Opportunities and Threats faced by companies in implementing the retakaful treaty Property Insurance program. The results of the 
Iwan Hermawan et.al. Evaluating the strategy to optimize the retakaful treaty property insurance: in the perspective of the Sharia General Insurance Company in Indonesia

evaluation of external factors are the average values obtained from internal and external sources that can be seen in the table below:

Table 6: the EFE Matrix

\begin{tabular}{|c|l|c|c|c|}
\hline No. & \multicolumn{1}{|c|}{ External Factors } & Weight & Rating & Score \\
\hline & \multicolumn{1}{|c|}{ Opportunity } & & & \\
\hline 1 & Kontrak treaty Asuransi Properti (1) & 0.111 & 4 & 0.397 \\
\hline 2 & Pangsa pasar asuransi syariah (2) & 0.106 & 4 & 0.392 \\
\hline 3 & Program retakaful treaty yang sesuai (3) & 0.111 & 3 & 0.381 \\
\hline 4 & Risiko - risiko yang dihadapi perusahaan (4) & 0.106 & 3 & 0.347 \\
\hline 5 & Payung hukum program retakaful treaty (5) & 0.111 & 3 & 0.333 \\
\hline & Ancaman & & & \\
\hline 1 & Ketersediaan perusahaan reasuransi syariah (6) & 0.106 & 3 & 0.302 \\
\hline 2 & Pemilihan security list (7) & 0.106 & 3 & 0.302 \\
\hline 3 & Kebijakan pemerintah (8) & 0.089 & 3 & 0.254 \\
\hline 4 & Pesaing (9) & 0.083 & 3 & 0.214 \\
\hline 5 & Ketersedian broker reasuransi (10) & 0.072 & 3 & 0.186 \\
\hline & Total EFE & $\mathbf{1}$ & & $\mathbf{3 . 1 0 7}$ \\
\hline
\end{tabular}

The EFE matrix can also be used to determine the opportunities and the main threats faced by company in optimizing the retakaful treaty Property Insurance program. The total weighted score on the EFE matrix is 3.107. This shows that the company's response is quite high in responding to the opportunities and threats of the Property Insurance crackaful treaty program. The main opportunity owned by the company is the production of retakaful treaty contracts which must be of high quality. While the main threat lies in the availability of sharia reinsurance company that will support the business of general sharia insurance companies.

\section{Analyzing Company's Position}

The company's position analysis in optimizing the retakaful treaty program Property Insurance can be analized using the Internal External Matrix (IE Matrix). IE Matrix illustrates the total score of internal and external strategic factors that affect the optimization of the Property Insurance retakaful treaty program. These internal and external strategic factors are analyzed quantitatively by weighting and ranking. In order to obtain a weighted and shortest score from each of these internal and external factors. There are 10 internal strategic factors (5 strengths and 5 weaknesses) and 10 external strategic factors (5 opportunities and 5 threats). According to the picture below, weighted and rated scores of each of these internal and external strategic factors can be seen in the EFE and IFE matrix. The total EFE score was 3,107 (high enough) and the total IFE score was 2.25 (almost strong enough). The weighted and the shortest total scores are entered into the IE matrix above. Based on IE matrix, the company's position is located in quadrant II, namely: Growth and build. The suitable strategy is to use intensive, forward, backward and horizontal integration. The intensive strategy consist of: Product development, Market Development and Market Penetration. Below is the company's position (IE matrix):

\begin{tabular}{|c|c|c|c|c|}
\hline & \multicolumn{4}{|c|}{ Total Score IFE } \\
\hline \multirow{5}{*}{ Score EFE } & & Strong & Medium & Weak \\
\hline & 4.0 & 3.0 & 2.0 & 1.0 \\
\hline & $\begin{array}{l}\text { High } \\
3.0\end{array}$ & I & $(2.25) \mathrm{II}$ & III \\
\hline & $\begin{array}{l}\text { Medium } \\
2.0\end{array}$ & (3.10) IV & $\mathrm{V}$ & VI \\
\hline & $\begin{array}{l}\text { Low } \\
1.0\end{array}$ & VII & VIII & IX \\
\hline
\end{tabular}

\section{Designing Alternative Strategy}

Strategy implementation is to implement the formulation of strategies that have been implemented previously. Other important things related to strategy implementation are: developing a culture that supports strategy implementation, creating effective organizational structures, directing marketing efforts, preparing budgets, developing and empowering information systems, and linking employee performance with organizational performance. 
Iwan Hermawan et.al. Evaluating the strategy to optimize the retakaful treaty property insurance: in the perspective of the Sharia General Insurance Company in Indonesia

Alternative Strategy Design If analyzed using a SWOT Analysis, the company's position in implementing the Property Insurance crackaful treaty program is in quadrant $\mathrm{I}(+0.59,+1.29)$ as shown in the table below:

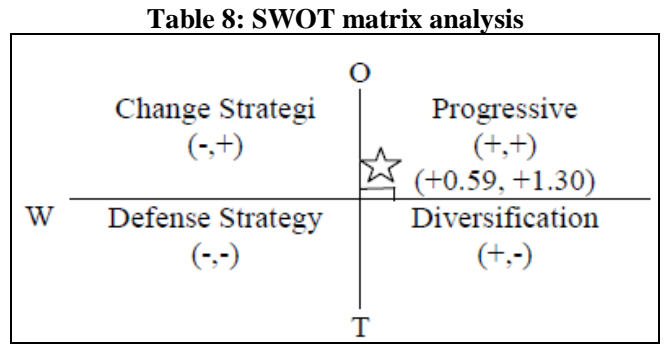

This value is obtained by calculating the difference between the total opportunity value (1.85) and the total threat value $(1,257)$ so that the value on the $y$-axis $(0.59)$ will be obtained. While for the $\mathrm{x}$-axis (1.30) is obtained from the calculation of the difference between the total value of strength (1.77) and weakness (0.47). The company's position in quadrant $\mathrm{I}$ with a progressive strategy which means changes in good conditions so that it is possible to continue to expand, increase growth and achieve maximum progress in utilizing retakaful treaty Property Insurance. An alternative strategy obtained by using a SWOT matrix analysis tool consisting of 4 quadrants, where the company's position in quadrant I with a Progressive strategy. The strategy is in accordance with the results of the company's position analysis using the IE matrix where the company is in quadrant II in the position of Growth and Build. Both company positions that were analyzed using IE matrix and SWOT matrix analysis showed a good company position by applying the right strategy. Therefore this research needs to do a priority strategy analysis.

\section{Determination Priority Strategy}

Priority strategies can be determined using QSPM analysis tools. By giving a value of attraction to each strategic factor in the form of strengths, weaknesses, opportunities and threats that form several alternative strategies. The value of a given attraction given on a scale of 1-4. Value 1 is given if not interesting, value 2 is given if it is somewhat interesting, value 3 is given if it is interesting, and value 4 is given if it is very interesting. After that, the highest total attractiveness score is the priority strategy chosen by the company and of course it is adjusted to the company's ability. The results of the priority analysis of the retakaful treaty strategy of Property Insurance using QSPM can be seen in the table below:

Table 9: Matriks QSPM
\begin{tabular}{|c|l|c|c|c|}
\hline No & \multicolumn{1}{|c|}{ Strategy } & Total TAS & Average TAS & Priority \\
\hline SO & With company retakaful experience can make a quality treaty contract & $0,42 \times 4=1,66$ & 0,83 & 1 \\
\hline SO & With the knowledge of HR can enlarge sharia market share & $0,40 \times 4=1,60$ & 0,79 \\
\hline ST & Company can get new reinsurer security list & $0.37 \times 4=1,30$ & 0,65 & 2 \\
\hline ST & With the knowledge and experience of HR can choose the best security list & $0.35 \times 4=1,23$ & 0,61 & 3 \\
\hline WO & Company can negotiate in treaty to achieve RTC and goals & $0.25 \times 3=0,61$ & 0,31 & 5 \\
\hline WO & Improvement SOP \& SLA & $0.24 \times 3=0,60$ & 0,30 & 6 \\
\hline WT & Company's vission, mission \& policy in line to reinsurer avilability & $0.20 \times 2=0,40$ & 0,20 & 7 \\
\hline WT & With improved SOP \& SLA, company can accept good risk and get claim recovery & $0.20 \times 2=0,39$ & 0,20 & 8 \\
\hline
\end{tabular}

Based on the QSPM method, it is known that the priority strategy of the company is: with reinsurance experience, the company can design a quality retakaful treaty contract. This priority strategy can minimize the emergence of problems from the implementation of the acceptance and handling of retakaful claims.
Evaluating the programs and implementation business process of retakaful treaty

According to interviews with internal sources and data from the reinsurance guidelines 2019 , it is noted that the type of property insurance retakaful treaty program used by PT. AJS is as follows: 
Iwan Hermawan et.al. Evaluating the strategy to optimize the retakaful treaty property insurance: in the perspective of the Sharia General Insurance Company in Indonesia

1. The retention value of the ceding company was originally reduced by $\mathrm{Rp}$. $1,500,000,000$ to $\mathrm{Rp} 1,000,000,000$.

2. To minimize the risk that becomes a burden on its own retention, PT. AJS implements twotypes of retakaful treaty capacities, namely:

\subsection{Proportional treaty capacity consisting of:}

a. Motor Vehicle Quota Share with a limit of Rp. 5,000,000,000 in proportion: $70 \%$ and $30 \%$.

b. Non-Marine Surplus with a total limit of Rp. 225,000,000,000 with the following:

- Property: Rp. 100,000,000,000

- Engineering: Rp. 50,000,000,000

- Miscellaneous: Rp. 75,000,000,000.

2.2. Non-proportional treay capacity which also consists of

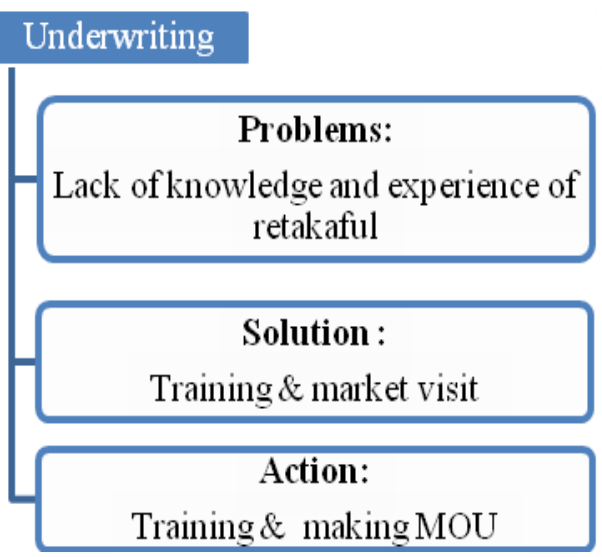

a. Marine Whole Account Excess of Loss with a total limit of Rp. 25,000,000,000

b. Non Marine Whole Account Excess of Loss with a total limit of Rp. 25,000,000,000

c. Catastrophic Whole Account Excess of Loss with a total limit of $\mathrm{Rp}$. $50,000,000,000$.

From the information of the intervieweeabove, the retakaful treaty Property Insurance has used the type of program: proportional Quota Share, Surplus and non-proportional Excess of Loss. The availability of retakaful treaty support capacity is quite large.

From the observation of the implementation business process of the retakaful treaty Property Insurance, there are problems solutions and actions in terms of underwriting and claim handling as follows:

\section{Claim Handling}

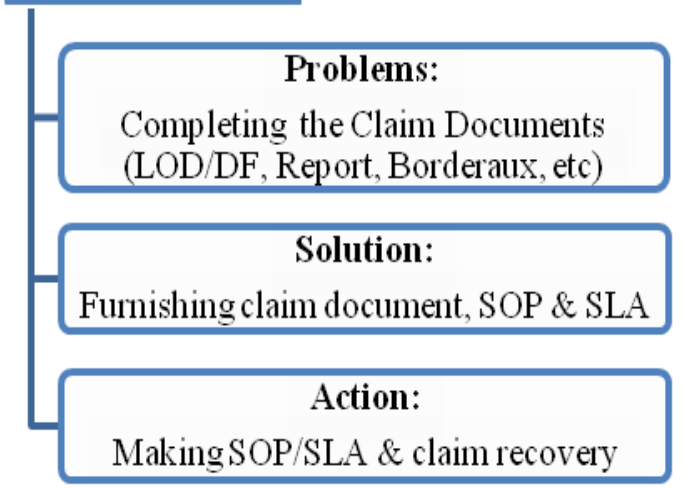

Making SOP/SLA \& claim recovery

view of the results obtained in this and in past studies on this topic as follows:

\section{DISCUSSION}

Based on findings in the author(s)'s experiments, we can interpret the findings in

\begin{tabular}{|l|c|l|}
\hline \multicolumn{1}{|c|}{ Company's Existing Strategy } & Alternative Strategy & \multicolumn{1}{c|}{ Priority Strategy } \\
\hline Company emphasized to banking & Progressive Strategy & $\begin{array}{l}\text { With the company's experience can } \\
\text { make a quality retakaful contract }\end{array}$ \\
\cline { 1 - 1 } Grabbing retail sector & Growth and Build Strategy & \\
\cline { 1 - 1 } Expanding corporate sector & & \\
\cline { 1 - 2 } Optimizing retakaful from domestic reinsurers & &
\end{tabular}

The company's existing strategy focused on the banking, retail business, corporate sector and keep optimizing retakaful from domestic reinsurers. On the other hand from the findings in view of the results obtained in this and in past studies, the company's priority strategy is: the company should make a quality retakaful contract. We think this priority strategy is in line with the last company's existing strategy: keep optimizing retakaful from domestic reinsurers. The weaknesses or pitfalls in the study is this priority strategy is especially for treaty. For facultative retakaful, the company should have another 
Iwan Hermawan et.al. Evaluating the strategy to optimize the retakaful treaty property insurance: in the perspective of the Sharia General Insurance Company in Indonesia

strategy to deal case by case directly to the reinsurers.

\section{CONCLUSION}

Based on the explanation above, it can be concluded that the alternative strategy obtained by using a SWOT matrix analysis tool consisting of 4 quadrants, where the company's position in quadrant I with a Progressive strategy. The alternative strategy is in line with the results of the company's position analysis using the IE matrix where the company is in quadrant II in the position of Growth and Build. The priority strategy of the company using QSPM is: with their insurance experience, the company can design a quality retakaful treaty contract. This priority strategy can minimize the emergence of problems from the implementation of the acceptance and handling of retakaful claims

According to the results of the evaluation of the business process scheme and the choice of the retakaful treaty program Property Insurance, there is little difference between retakaful and conventional reinsurance. In retakaful treaty, the risk mechanism is a risk sharing so in risk management, the sharia insurance company as the ceding company must share the wakalah fee which they have been received to the sharia reinsurance company. Whereas in conventional insurance is risk transfer, the conventional reinsurance company will give a reinsurance commission to the insurance company which has given them the business.

\section{Acknowledgement: None}

\section{Conflict of Interest: None Source of Funding: None}

\section{REFERENCES}

1. Aznan Hasan, (2011), Sharia issues in the operation of retakaful and reinsurance: a preliminary exploration from shariah perspective, IIUM Law Journal Vol. 19 No. 2, 2011.

2. Asmak Ab Rahman. 2009.Exploring sharia'ah views on the practice of takaful company reinsuring with reinsurance company.ISRA Shari'ah Conference on Takaful.[internet]. [Diakses pada 2019 August 12]. Tersedia pada: http://mbri.ac.ir/userfiles/file/Islamic Banking.

3. Asmak Ab Rahman,Wan Marhaini Wan Ahmad, Ahmad Hidayat Buang. 2011.Can a takaful company reinsure with a reinsurance company?.African Journal of Business Management.5 (30): 11768-11778.

4. Aysha Al-Salih. 2014. Takaful and Conventional General Insurance: Analysing Muslim Consumers' Perceptions and Choices in the UK and Saudi Arabia.[tesis]. United Kingdom (GB): School of Management Royal HollowayUniversity of London.

5. Aznan Hasan. 2011.Sharia issues in the operation of retakaful and reinsurance: a preliminary exploration from shariah perspective.IIUM Law Journal. 19(2): 149178.

6. Bagas Heradhyaksa, Ruzian Markom. 2018. Jurisdiction of Sharia Supervisory Board in Indonesian Takaful Industry. IOP Conf. Series: Earth and Environmental Science Journal. 175 (1): 1-7.

7. Chas E. Hall. 1985. Property and Pecuniary Insurances. United Kingdom (GB): Chartered Insurance Institute.

8. David 2004. Manajemen Strategis Konsep Konsep. Edisi ke-9. Jakarta (ID):Ahli bahasa Kresno Sansu: Indeks.

9. Dickson. 2007. Introduction to Insurance. United Kingdom (GB): Chartered Insurance Institute.

10. Graita G. Jatmiko. 2017. Strategi pengembangan asuransi usaha tani padi PT. Asuransi Jasa Indonesia. [tesis]. Bogor (ID): Institut Pertanian Bogor.

11. Hamim Syahrum Ahmad Mokhtar. Izwayu Abdul Aziz, Noraziyah Md Hilal. 2017. Corporate demand for general takaful in Malaysia. ISRA International Journal Islamic Finance.9 (2): 164-184.

12. Iman Van Levyveld, Franka Liedorp, Manuel Kampman. 2009. An empirical assessment of reinsurance risk.Journal of Financial Stability. 7(4): 191-203.

13. Issa Qaed, Elvan Syaputra, Faridl Noor Hilal, Muhammad Febriansyah, Muhammad Majdy Amiruddin, Muhammad Ridhwan Ab. Aziz, 2014.Maslahah as an Islamic source and its application in financial 
Iwan Hermawan et.al. Evaluating the strategy to optimize the retakaful treaty property insurance: in the perspective of the Sharia General Insurance Company in Indonesia

transactions.quest journals. Journal of Research in Humanities and Social Science. 2 (5): 66-71

14. Kamarudin Sharif. 2004.TakafulDevelopment and chalenges over 20 years of its existence in Malaysia. Jurnal Pengurusan. 23(3): 13.

15. Khalid Al Amri, J. David Cummins, Mary A. Weiss. 2014.Economies of scope, organizational form and insolvency risk: evidence from the takaful insurance industry. SSRN Electronic Journal.10 (1016): 15-050.

16. Khalid Al-Amri, Mohammad Zakir Hossain. 2015.A survey of the Islamic insurance literature-takaful. International Journal of Economic Research. 14 (9): 173-185.

17. Kevin Griffith. 2010. Insurance Business and Finance. United Kingdom (GB): Chartered Insurance Institute

18. Lesław Gajek. Dariusz Zagrodny. 2000.Insurer's optimal reinsurance strategies. Mathematics and Economics Journal. 27 (1): 105-112.

19. Maryasin Abdul Hamid. 2018.Analysis of the implementation of reinsurance practices in shari'a insurance companies in Indonesia.INCISST Journal. 1(1): 1-19.

20. Martin Briers. 2009. Commercial Property and Business Interruption Insurances. United Kingdom (GB): Chartered Insurance Institute.

21. Matt Davison, Darrell Leadbetter, Bin Lu1, Jane Voll. 2016. Are Counterparty Arrangements in Reinsurance a Threat to Financial Stability?.[internet]. [Diakses pada 2019 August 12]. Tersedia pada: https://www.bankofcanada.ca/wpcontent/uploads/2016/08/swp2016-39.pdf.

22. Muhammad Syakir Sula. 2004. Asuransi Syariah (Life and General) Konsep dan Sistem Operasional. Jakarta (ID): Gema Insani

23. Mehedi Ibne Rahim. 2014.Takaful viability with hindsight of uk marine insurance: paradigm splitting the islamic viewpointswill insurance really ever be considered halal?.International Journal of Business. Economics and Law. 5 (4): 11-29.

24. Mohammad Khan. 2008. Islamic Insurance (takaful and retakaful). [internet]. [Diakses pada 2019 August 12]. Tersedia pada: http://www.assaif.org/content/download/805 /6056/file/m
25. Muhammad Rawwas Qal'ahji, Hamid Sadiq Qunaini. 1988. Dar'an Nafa'is Beirut Lebanon (LB): Kitab Shohih Qoshosun Nabawi.

26. M.S Najatullah. 2013.Principle of Takaful.United Kingdom (GB): Chartered Insurance Institute

27. Nurul Ichsan. 2016.Takaful Keluarga, Takaful Umum and Retakaful, Retakaful is the protection of takaful company itself. Jurnal ekonomi Islam. 6(1): 1 - 118 .

28. Nina Sari Annisa. 2014. Analisis risiko dan evaluasi strategi asuransi ternak sapi studi kasus: pilot project PT. Asuransi Jasindo.[tesis]. Bogor (ID): Institut Pertanian Bogor.

29. Paul.2009.Reinsurance. United Kingdom (GB):The Chartered Insurance Institute

30. Phillip Morley. 2005. Marketing. United Kingdom (GB): The Chartered Insurance Institute

31. Ridarmelli and A. Dewantoro Marsono. 2009.Alternatif Perhitungan RBC (Risk Based Capital)Upaya Menjaga Daya Saing Perusahaan Reasuransi Syariah.[tesis]. Jakarta (ID): Institut Perbanas.

32. Rosmi Yuhasni Mohamed Yusuf. 2011. Revisiting and redefining the concept of the retakaful and the viability its model in Malaysian Takaful industry.Business and Management Quarterly Review Journal. 2(4): 20-32.

33. R.A LitaWulandari. 2017. Perencanaan strategik unit usaha pembiayaan syariahmenuju spin off (studi kasus Adira Finance). [tesis]. Bogor (ID): Institut Pertanian Bogor.

34. Rangkuti F. 2002. Analisis SWOT: Teknik membedah Kasus Bisnis. Jakarta (ID): Gramedia Pustaka Utama

35. Ryan Ardiansyah Ridwan. 2009. Strategi Prioritas bisnis ritel terhadap pencapaian target RKA BRI Bogor Dewi Sartika. [tesis]. Bogor (ID): Institut Pertanian Bogor.

36. Sheila $\mathrm{Nu} \mathrm{Nu}$ Htay. Mustapha Hamat. Wan Zamri Wan Ismail, Syed Ahmed Salman. 2014.Are takaful operators at the simpathy of Retakaful Operators in Malaysia. The Sosial Science Medwell Journals. 9 (2) 108111.

37. Sheila $\mathrm{Nu}$ NuHtay. Mustapha Hamat. Wan Zamri Wan Ismail, Syed Ahmed Salman. 2014.Retakaful (Islamic Reinsurance): Historical, Shari'ah and Operational Perspectives. World Applied Sciences 
Iwan Hermawan et.al. Evaluating the strategy to optimize the retakaful treaty property insurance: in the perspective of the Sharia General Insurance Company in Indonesia

Journal (Innovation Challenges in Multidisciplinary Research \& Practice). 30 (10): 185-190.

38. Sunarto. 2019. Strategi pengembangan asuransi tanaman kelapa sawit dengan dengan pendekatan model bisnis kanvas (studi kasus PT. Asuransi Tripakarta). [tesis]. Bogor (ID): Institut Pertanian Bogor.

39. Ujang Sumarwan. Hartoyo. Idqan Fahmi. 2018. Metode Riset Bisnis dan Konsumen. Edisi revisi 2018. Bogor (ID): Penerbit IPB Press
40. Wheelen. Thomas L. J. David Hunger. 2012. Strategic Management and Business Policy ed. 13. New Jersey (US): Pearson Education.

How to cite this article: Iwan Hermawan, Noer Azam Achsani, Laily Dwi Asyanti. Evaluating the strategy to optimize the retakaful treaty property insurance: in the perspective of the Sharia General Insurance Company in Indonesia. International Journal of Research and Review. 2022; 9(1): 378-391. DOI: https:// doi.org/10.52403/ijrr.20220145 